\title{
A CONCEPTUAL MODEL OF ETHICAL SERVICE COMPLIANCE AND CULTURE FOR BANKING SECTOR
}

\author{
Basuki Rachmat ${ }^{1, *}$, Surachman ${ }^{1}$, Armanu ${ }^{1}$, and Fatchur Rohman ${ }^{1}$ \\ ${ }^{1}$ Management Department, Faculty of Economics and Business, Brawijaya University.
}

ABSTRACT - The objective of this study is to propose a conceptual model of ethical service compliance and culture for the banking sector in order to comply with ethical service and local wisdom which has been argued as one of the specific domains. The review of the literature was conducted to examine the existing service culture model and theoretical concept. PICO (Problem, Intervention, Comparison, and Outcome) technique was utilised to identify the service domains which suit the banking sector. This study found that service culture needs to include the service domains since the early stage of the recruitment process and training. It is also important to consider the service reward, service co-creation, service transformation, service climate dan service orientation as the drivers of ethical service compliance and culture, which drives toward an excellent service value.

ARTICLE HISTORY

Received: 3-9-2020

Accepted: 9-11-2020

KEYWORDS

Service Culture, Ethical

Service Compliance, Ethical

Service Culture, Excellent

Service

\section{INTRODUCTION}

Economic growth in the era of the industrial revolution 4.0, which was dominated by technological developments has led to the rising in business competition. Responding to the various changes that have occurred, many banks in Indonesia have taken strategic steps and policies to maintain the excellence of banking services based on meeting customer needs through the provision of quality products and services. A series of innovative banking products and services were developed by optimising the latest technological advances to pay attention to customer experience. Efforts to promote a culture of innovation, cooperation and effective collaboration in every line are expected to increase readiness in adapting to changes. Therefore, the demand for service quality becomes a challenge in an effort to meet the expectations of all parties. In addition, the increasingly complex development of the business world has resulted in the accumulation of economic transactions that cannot be separated from banking services (Fahmi \& Wibowo, 2020). With the increasing level of dependence on banking services, there is a gap in ethical behaviour and service culture in every level of the individuals involved in it.

In relation to business ethics as a study of morality that focuses on an organisation, Kamarudin et al. (2020) claimed that "normally, business ethics studies will be divided into three main categories which are systematic issue, corporate issue and individual issue." Therefore, the banking code of ethics has a holistic trend in which all internal parties must comply in providing services to external parties. This is intended to understand that internal party compliance in maintaining discipline and responsibility is related to high integrity and professionalism in carrying out its operational activities. The legality of BRI's code of ethics was stated in the Joint Decree of the BRI's Board of Commissioners and Directors Number: 06-KOM/BRI/12/2013 and Nokep: S.65-DIR/DKP/12/2013 concerning BRI's Code of Ethics while at Bank BCA, it was stated in the Decree of the Board of Directors No. 778/SK/DIR/95 Concerning Code of Ethics for BCA Bankers. Therefore, the code of ethics is fundamental for creating an ethical service culture in line with systematic, corporate and individual issues. Frinaldi et al. (2019) explained that "to improve value and image of an organisation, a service culture is needed to increase work satisfaction." This is in line with the opinion of Grönroos (2007) which stated that "a culture where an appreciation for good service exists and was giving good service to internal as well as ultimate, external customers is considered by everyone as a natural way of life and one of the most important values "(Davis \& Gautam, 2011; Pant, 2013).

On the other hand, Sajari et al. (2019) described that "the stories of collapse companies such as Enron, Tyco, and World Com proven that ethics and integrity are the most essential elements in governance that affect not only organisational effectiveness but also survival skills". The implied meaning of this statement is that the survival skills behind ethics and integrity can at least be anticipated by an ethical service culture, or at least as a material of reflection for banking management. Taking into account that the best possible system is built with the latest technology, everything depends on the ethical behaviour of each individual in running the business.

This situation has proven that ethical service culture research has yet to be touched in its development, which is a unique attraction for further research. Therefore, this study aims to propose a conceptual model of ethical service compliance and culture for the banking sector by raising local wisdom as one of the specific domains. This is intended to 
contribute in the form of references to the banking world, enrichment of literature in the world of knowledge, and development opportunities for further research.

\section{LITERATURE REVIEW}

Service culture literature which is used as the basis of research and its modelling, has hardly been touched since its publication, including:

1. The results of research by Ostrom et al. (2010) which offered five main principles of service culture, consisting of (1) Recruiting, training and rewarding associates for a sustained service culture, (2) Developing a service mindset in product-focused organisations, (3) Creating a learning service organisation by harnessing employee and customer knowledge, (4) Keeping a service focus as the organisation grows and evolves, (5) Globalising a service organisation's culture across different countries.

2. The research outcomes by Davis and Gautam (2011), which are the development of research results by Ostrom et al. (2010) focus on value creation orientation. By using four main principles (excluding the 5th principle), they developed a service culture conceptual model based on service value with eight dimensions along with a hypothesis equation consisting of (1) service training, (2) service rewards, (3) service co-creation, (4) service transformation, (5) service climate, (6) service orientation, (7) service encounters, and (8) service value.

3. The research by Pant (2013) under the supervision of Robert Davis and Ravi Bhat who continued the research of Davis and Gautam (2011), conducted a conceptual reconstruction of the model proposed by Davis and Gautam (2011) and changed the basis of service transformation-oriented research using the same eight dimensions.

However, the conceptual model which includes its supporting dimensions, has not reached perfection and touched only on local wisdom holistically.

The present study which is closely related to local wisdom has observed banking entities in Indonesia for the year of 2020 and found that ethical values has been practiced as a form of local wisdom in routine activities by the majority in all banking entities. This is established due to the proper recruiting and training processes, adhering to ethics, and implementing fairness in business routines. According to Kamarudin et al. (2020), "ethics is the study of morality which is defined as a rule that an individual or a group of people has about what is good or evil, or right or wrong". In a business perspective, ethics has been seen as a moral standard that measures a business, institution and organisation's behaviour (Trevino \& Weaver, 2013). For this reason, the grounding of ethics as a form of local wisdom into service culture is fundamental and depends on the leadership of the business entity. As mentioned by Ishak et al. (2019), "leaders are considered as tone at the top that shapes the direction and ethical culture of an organization". Leaders are responsible for the conduct of the organisation. Ethical leadership is known as moral managers who consider ethics as necessary. They will ensure that the importance of ethics is communicated well to their subordinates. Thus, theoretically, the conceptual model of service culture still needs improvement and alignment with the ethical values of local culture.

\section{METHOD}

This qualitative research employed the PICO method (Eriksen \& Frandsen, 2018; Roever, 2018; Howard, 2020), which is often found in the medical world as a method of seeking clinical information. Perhaps, this is the first research conducted in a social sphere. The PICO method thought line is an acronym stage consisting of 4 components, including:

- $\quad \mathrm{P}$ (patient, population, problem) leads to the question of how to describe the problem or the critical characteristics of the problem that arises.

- I (intervention, prognostic factor, exposure), leads to the question of what intervention is considered to overcome the problem or what must be done to overcome the problem.

- C (comparison, control), leads to the question of what is the comparison of the selected intervention to deal with the problem, which can be in the form of theory and / or other research results.

- $\mathrm{O}$ (outcome). Leads to the question of what the intervention is trying to achieve: size, improvement, or impact.

The use of the PICO method tends to make it easier to describe several problem statements according to the conceptual model to be studied. In order to strengthen the analysis process, this study used interactive data analysis as proposed by Miles et al. (2014). Meanwhile, in order to intensify the results of the analysis, this study took samples from 2 best category banks for the 2020 FORBES version and the recipients of the "Banking Service Excellence Awards 2020", namely Bank BRI (government commercial bank) and Bank BCA (private commercial bank) through the published 2019 Annual Report. 


\section{RESULTS \& DISCUSSIONS}

Problem

This research raised ethical issues in banking entities which are still characterised by a service culture oriented towards conventional banking modernity. In general, the applied service culture tends to focus on banking entities that are considered advanced and of international standard. Customer problems that are laden with local wisdom often collide with services that do not holistically meet expectations. Ethical and religious factors are often the constant concerns to be discussed in the scope of service. Discomfort occurred when the Indonesian Ulema Council (MUI) and the Government of Indonesia established Bank Muammalat on November 1, 1991. Although there have been many sharia-based banks established until today, they remain polemic due to their conventional governance. As an alternative bank besides conventional banks, the Islamic banking entity continues to strive to find its identity amidst global banking competition. One of the breakthroughs that is not conceptualised is the practice of service-oriented to local wisdom or often referred to as an ethically-based service culture. This is where this research originated and will be developed to the modelling level.

\section{Intervention}

Theoretically, the service culture conceptual model is based on the research results of Ostrom et al. (2010) which offers five main principles of service culture. Furthermore, Davis and Gautam (2011) which focused on value creation orientation based on four main principles of service culture (excluding the 5th principle), offered a conceptual model with eight dimensions along with its hypothesis equations consisting of (1) service training, (2) service rewards, (3) service co-creation, (4) service transformation, (5) service climate, (6) service orientation, (7) service encounters, and (8) service value. Finally, Pant (2013) which employed the same eight dimensions, conducted a conceptual reconstruction of the Davis and Gautam (2011) model on a service transformation-oriented research focus.

From a contemporary perspective which is closely related to local wisdom, the majority of Indonesia's population is Muslim. Thus, the culture that develops in the community is coloured with Islamic values - no exception to alignment in the joints of the business life. Based on the analysis of the research outcomes of Davis and Gautam (2011) and Pant (2013), this study questions if recruiting should be considered as one of the indicators (dimensions). This is because the recruiting indicator is closely related to the filtering of human resources which is also related to ethics and religion as the core of local culture. In additon, recruiting has the potential to obtain quality human resources who are expected to enforce the code of business ethics. This is in line with the main principles of Ostrom et al. (2010) which is used as the basis for service culture development that is "recruiting, training and rewarding associates for a sustained service culture." Thus, recruiting should be considered a significant dimension in the service culture.

\section{Comparison}

At the theoretical level, in order to accommodate recruiting into a significant dimension in service culture, comparative steps will be taken using the following thinking patterns:

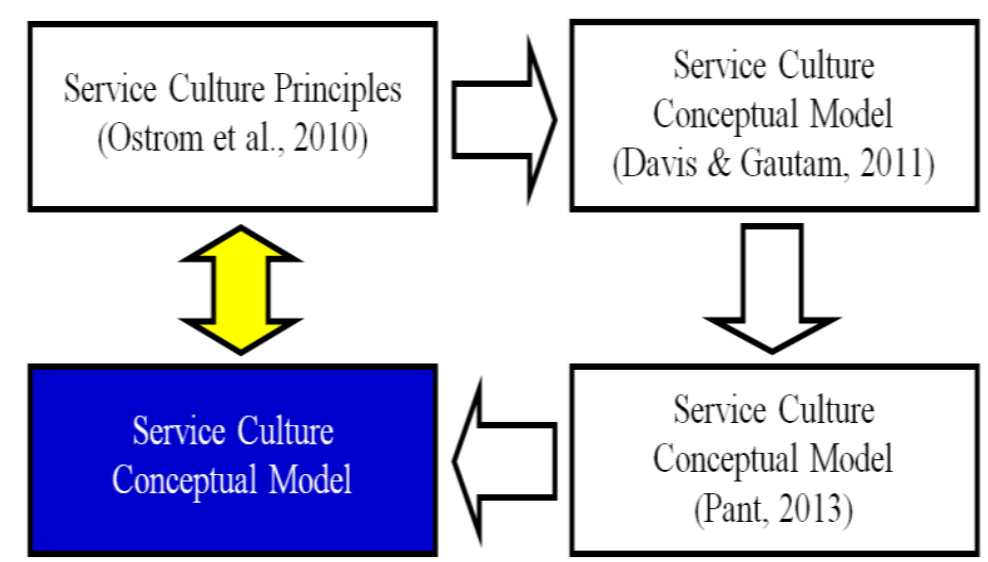

Figure 1: Theory of Comparative Mindset

Based on a collaborative analysis of 4 primary service culture principles by Ostrom et al. (2010), the service culture conceptual model by Davis and Gautam (2011) and Pant (2013), another crucial dimension needs to be added to the eight service culture dimensions, which is recruiting. This is in line with the statement of Pant (2013), "the recruitment process plays an important role in showing the characteristics of an organisation's service." Similarly, Davis and Gautam (2010) also claimed that "increasing employee supply through recruitment and training can lead to the inculcation of a service culture in a workforce." Therefore, eight service culture dimensions are proposed into nine dimensions consisting of (1) Service Recruiting, (2) Service Training, (3) Service Rewards, (4) Service Co-creation, (5) Service Transformation, (6) Service Climate, (7) Service Orientation, (8) Service Encounters, and (9) Service Value. The following is a proposed service culture dimension change roadmap: 


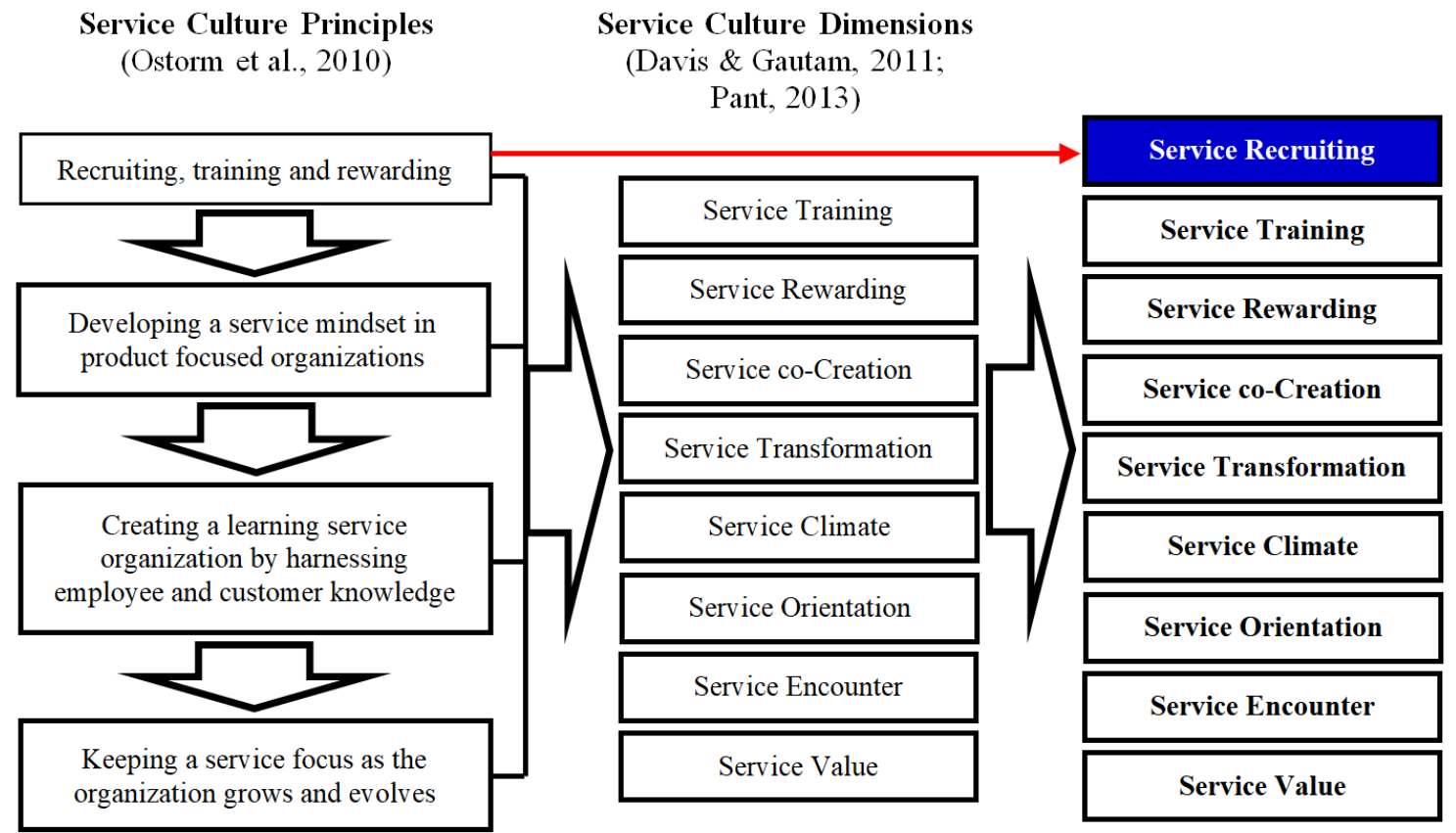

Figure 2: Roadmap for changing Service Culture Dimensions

Source: Adapted from Ostorm et al. (2010) \& Davis and Gautam (2013)

Thus, the addition of the recruiting dimension is one of the dominant aspects that should not be eliminated in building a service culture conceptual model. As a form of comparative proof, all banks in Indonesia place the recruiting dimension as an essential part of realising a service culture in providing services to stakeholders. This can be proven through the publication of the 2019 Annual Report of all banks in Indonesia, that the recruiting dimension is placed as a critical component to be reported to the public as a form of accountability. After an in-depth study regarding the addition of the recruiting dimension to the service culture dimension, further improvements are proposed as follows:

\section{Service Culture Dimensions}

From the eight dimensions of service culture by Davis and Gautam (2011) and Pant (2013), it is necessary to add one dimension of service recruiting so that it becomes nine dimensions which as a whole consist of service recruiting, service training, service reward, service co-creation, service transformation, service orientation, service climate, and service encounter, and service value. As for conceptually, the relationship between dimensions is described as follows:

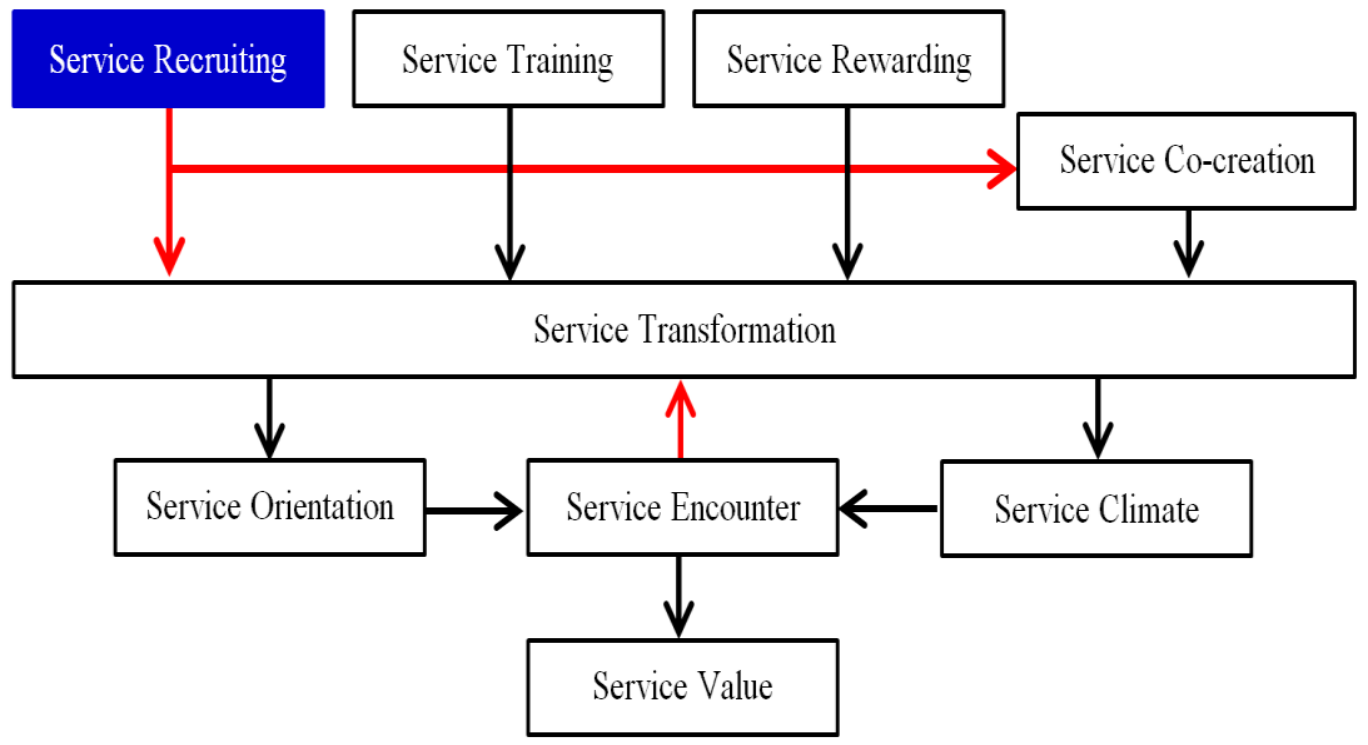

Figure 3: Relationships between service culture dimensions 


\section{Recruiting}

In the 2019 BRI Bank Annual Report on page 329, it was stated that in order to attract the attention of millennials and generation $\mathrm{z}$ in talent wars, BRI continues to innovate in the field of recruitment to get the best talents. In 2019, the erecruitment application can be used for the entire recruitment process, starting from receiving application files to documenting the results of the recruitment of BRI employees throughout Indonesia (page 336). Besides, in order to find the best talents, BRI implements the BRILiaN Scholarship program. This program is intended to provide scholarship assistance for outstanding students and as an early recruitment route for the best talents to join BRI.

\section{Quality human resource}

Meanwhile, in the 2019 BCA Bank Annual report (page 244), it was stated that in order to ensure the continuous availability of quality human resources, BCA prepares a comprehensive and sustainable work plan. This begins with recruiting HR with the best ability. Thus, both banks have so far been proven to have placed the recruitment dimension as a vital part of their annual agenda. In essence, the recruitment process plays a vital role in order to demonstrate the service characteristics of the organisation (Pant, 2013). This is to ensure an increase in the provision of employees in order to lead to the inclusion of a service culture in a workforce (Davis \& Gautam, 2011). By obtaining the right, reliable and trustworthy human resources, it is hoped that they can act as strategic partners and agents of change. Frei (2008) emphasised that senior members of an organisation must focus on the process of recruiting and selecting to filter the right applicants. Given that senior members (leaders) are responsible for organisational behaviour (Wan et al., 2017), ethical leadership, known as moral managers, considers ethics essential and will certainly be communicated well to their subordinates (Ishak et al., 2019) and prospective employees at the time of recruitment. Davis and Gautam (2011) emphasized that "recruitment is one of the biggest things" Thus, the right, reliable and resilient service recruiting as part of the main foundation of an ethics-based service culture in addition to service training and service rewards, has the potential to create service co-creation to support service transformation.

\section{The primary foundation of a service culture}

Consists of service recruiting, service training and service rewards, either partially or simultaneously, has the potential to form service co-creation. Thus, service recruiting, service training and service rewards as a stimulant dimension should be considered grounding their ethical values to create quality service co-creation. Based on the results of empirical studies through observation and literature studies, service recruiting, service training and ethics-based service rewards have the potential to create employee job satisfaction in realising innovative and creative performance quality in service delivery. Meanwhile, an empirical review regarding the dimensions of service training and service rewards, that:

\section{Service Training}

It was stated in the 2019 BRI Bank Annual report (pages 336- 337) that "in order to improve the quality of BRI's human capital to support the achievement of superior performance, in 2019, BRI has updated the policy for Certification Education for Workers." This is intended to "ensure that BRI Group employees are competent and have Talent, to jointly achieve BRI's Vision" Home to The Best Talent "and towards Excellent Human Resources for Advanced Indonesia". Meanwhile, in the 2019 Annual Report of Bank BCA (page 244), it was stated that "... provides adequate training and development for every employee and ensures the readiness of future leadership successors. BCA pays attention and efforts to instil an agile mindset and way of working in order to be able to adapt to the challenges of changing business and technology today and even in the future. "For this reason, to provide the best service to its customers, Bank BRI and Bank BCA have provided a special budget for employee training programs by establishing a strict schedule, and constantly evaluating the program and the results of the training. This is in line with the opinion of Ostrom et al. (2010), Lytle and Timmerman (2006), Chen (2005), that "training is an important process provided by an organisation to employees to develop their skills and make them enthusiastic about providing excellent service to customers." This is also similar to the opinion of Davis and Gautam (2011), that "service training is an important element in improving service quality in a service-focused business."

\section{Service Rewards}

This is evident that Bank BRI and Bank BCA implemented a policy of rewards and rewards, not only financial but also non-financial to create mutual welfare. For this reason, some of which are related to reward and reward policies are handled by a particular unit (human capital) whose task is to plan, implement/realise, and evaluate. As stated by Ostrom et al. (2010) and Schneider et al. (1998), service rewards positively affect service transformation (Pants et al., 2013). According to Lytle and Timmerman (2006), service rewards are a way for organisations to provide incentives and rewards to employees for the value they create from the perspective of customers and other stakeholders (Davis \& Gautam, 2011; Pants, 2013). Pointing out that good managers can develop their service delivery by persuading and inspiring their employees through setting the objective, authorising them and giving them rewards for achieving the objectives and making the service process thrive (Hui et al., 2007). Therefore, based on the results of the study by Davis and Gautam (2011), it can be assumed that rewards form part of the motivation that can lead to changes in service employee development. Rewards also have an indirect effect on service delivery behaviour (orientation), effort and competence. Thus, reward as a vital part of HRM in giving awards to HR performance is indicated to have a significant role in service 
transformation in realising the strategic objectives of the organisation/company and its effect on significant changes in service functions.

\section{Service Co-Creation}

Meanwhile, an empirical review of the service co-creation dimension in the 2019 BRI Bank Annual report on page 45 stated that “... competency-based human resource management and internalisation of the company's core values (Integrity, Professionalism, Trust, Innovation and Customer-Centric), we believe that the company will always be able to win the competition and grow sustainably". "In this case, innovation means continuously utilising the ability and expertise to find new solutions and ideas to produce products/policies in response to the challenges of the company's problems (page 87)". Likewise, BCA Bank, with its values concerning team cooperation, shows an increase in the realisation of co-creation. Furthermore, in fact, co-creation is an important aspect through work and service culture in supporting the achievement of the company's vision and mission. As explained by Vargo and Lusch (2008a), "service innovation helps create service co-creation through the combined efforts of customers and service employees to share their knowledge". Furthermore, Ostrom et al. (2010) argued that "service co-creation forms an integral component for sustainable Service Transformation". This is similar to Schneider et al. (1998) which explained, that "co-creation also affects the service climate by encouraging the exchange of opinions, expertise, the value of service and by maintaining its quality through the efforts of customers and employees." Thus, the relationship between service co-creation and service transformation is essential in the implementation of service culture because the nature and direction of change is driven more by stakeholders than the organisation itself.

\section{The circular service culture dimension}

Consisting of service transformation, service climate and service orientation, which is centred on the service encounter dimension, sustainably affects service transformation in realising service value. Dimensional circulation development in realising service values include service transformation, service orientation, service climate and service encounters. As Davis and Gautam (2011) argued, "service transformation has an impact on service orientation through a continuous transformation of activities to improve service quality and introduce new concepts during service encounters." Furthermore, Liao and Chuang (2007) as quoted by Davis and Gautam (2011) explained that "service transformation shows the process of maintaining high-quality service delivery to and among all service employees in a way that continuously fosters a positive service climate. Therefore, service transformation has an impact on the service climate by developing service standards within the organisation and creating a service orientation." Thus, service encounters are also one of the three dimensions other than the main fundamental dimensions of service culture development that can trigger sustainable service transformation to influence service orientation and service climate in realising service value.

In the 2019 BRI Bank Annual Report (page 45), it was stated that "improvement in competency-based human resource management and internalisation of the company's core values (Integrity, Professionalism, Trust, Innovation and Customer-Centric), we believe that the company will always be able to win the competition and grow sustainably. Our confidence is further enhanced by the recognition and awarding of the company's achievements and achievements by various credible institutions, both domestic and international institutions." Likewise, in the 2019 Annual Report of the Bank BCA (page 33), it was stated that "human resources are an important part of maintaining the company's sustainable growth performance. Responding to increasingly complex customer needs and rapid technological changes, BCA is committed to continuously improve the competence and capabilities of qualified human resources as well as being responsive or "agile" in responding to changes in an increasingly dynamic business environment."

Thus, the relationship between service transformation, service climate and service orientation is vital in the implementation of service culture because continuous service changes not only affect services from an implementation perspective but also how they are perceived (Pant, 2013). The service orientation dimension strongly influences service encounter dimensions, and the service climate dimension will affect service transformation on an ongoing basis, considering service encounters as a form of service meeting with customers in realising service value. This situation allow creative and innovative steps to emerge which can affect the service orientation dimension and service climate dimension through service transformation.

Thus, the outcome in the form of a service culture conceptual model based on ethics that focuses on sustainable transformation to create quality service values, is described as follows: 


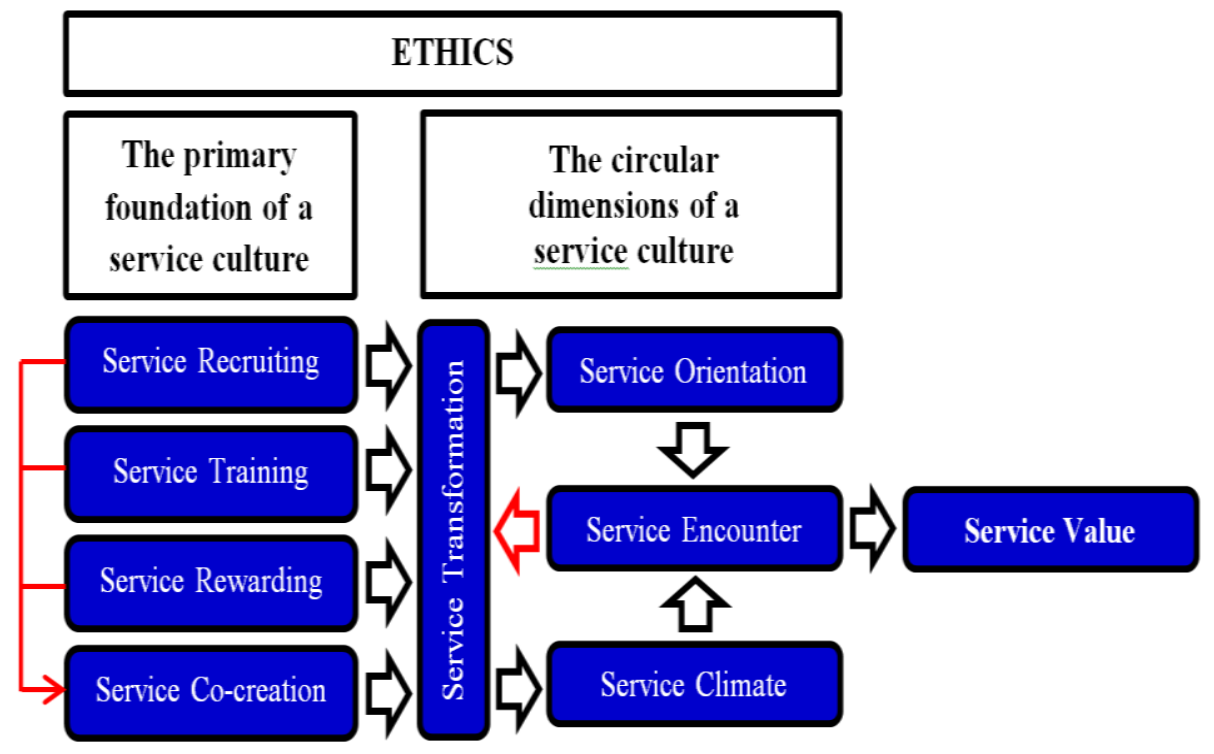

Figure 4: Ethics-based service culture

In this case, the service culture, which consists of the main foundation and the circular dimension, should be protected by ethical values as a form of local wisdom that is aligned with customer expectations.

\section{CONCLUSIONS}

Service culture should be developed since the recruitment process, considering that recruitment is an initial process of determining employees who are expected to carry out their functions according to the code of ethics established by the company. As it is known, the preparation of a company code of ethics always pays attention to meeting the needs of all parties who do not violate the law. In this case, the law as a social rule cannot be separated from the overall values in a society. It can even be said that law is a reflection of the values that live in society. Thus, a service culture under the umbrella of ethics is expected to be able to realise quality service values.

This qualitative research on service culture based on ethical values is expected to be able to encourage the creation of quality human resources, considering that HR, as a strategic partner and agent of change, can keep up with technological developments in the era of the Industrial Revolution 4.0. The results of this study have yet to reach the peak of comprehensive results. Therefore, it is hoped that in further research, service culture research models can be adequately developed.

\section{REFERENCES}

Annual Report 2019 PT. Bank BCA, Tbk

Annual Report 2019 PT. Bank Rakyat Indonesia.

Chen, K.P. (2005). External recruitment as an incentive device. Journal of Labour Economics, Vol.23, No.2, Pp.259-278. DOI: $10.1086 / 428024$

Davis, R., \& Gautam, N. (2011). Conceptualising service culture. Retrieved October 5, 2019, via website https://thedomm.files.wordpress.com/2011/05/davis-gautam-blog-version-2011.pdf

Eriksen, M.B. \& Frandsen, T, F. (2018). The impact of patient, intervention, comparison, outcome (PICO) as a search strategy tool on literature search quality: a systematic review. Journal of the Medical Library Association. Volume 106, Issue 4, Pp.420-431. DOI:10.5195/jmla.2018.345.

Fahmi, A.S.R. \& Wibowo, T.C. (2020). Perkembangan Teknologi Dan Kualitas Pelayanan Nasabah Pada Baitul Maal Wa Tamwil Latansa Gontor. Jurnal Kajian Bisnis. Vol.28, No.2, Hal.207-216. DOI:10.32477/jkb.v28i2.211

Frei, F.X. (2008). The four things a service business must get right. Harvard Business Review, Vol.6, No.4, Pp.70-80.

Frinaldi, A., Embi, M.A., Bila, A. (2019). Service Culture Chain: Increasing Public Satisfaction. IAPA Proceedings Conference, Pp.5867. DOI:10.30589/proceedings.2019.219

Grönroos, C. (2006). Adopting a service logic for marketing. Marketing Theory. Vol.6, Issue 3, Pp.317-333. DOI: $10.1177 / 1470593106066794$

Howard, C. (2020). Subject and Course Guides: Evidence-Based Medicine: PICO. Retrieved October 10, 2020, via website https://researchguides.uic.edu/c.php?g=252338\&p=3954402

Hui, H., Chiu, W., Yu, P., Cheng, K., \& Tse, H. (2007). The effects of service climate and the effective leadership behaviour of supervisors on frontline employee service quality: A multilevel analysis. Journal of Occupational and Organizational Psychology, Vol.80, Issue:1, Pp.151-172. DOI:10.1348/096317905X89391 
Ishak, N.K., Haron, H., Ismail, I. (2019). Examining Factors That Could Lead To Unethical Behaviour In Institutions Of Higher Learning. Journal Of Governance And Integrity (JGI). Vol. 3, Issue 1, Pp.10-19. DOI: 10.15282/jgi.3.1.2019.5418

Kamarudin, D., Zakaria, H., Azit, A. (2020). Different Ethical Perspectives Justifying Reasonings Behind a Person's Actions: A Case Study on a Private Institution in Malaysia. Journal Of Governance And Integrity (JGI). Volume 3, Issue 2, Pp.09-16. DOI:10.15282/jgi.3.2.2020.5306

Liao, H., \& Chuang, A. (2007). Transforming Service Employees and Climate: A Multilevel, Multisource Examination of Transformational Leadership in Building Long-Term Service Relationships. Journal of Applied Psychology, Vol.92, Issue 4, Pp.1006-1019. DOI:10.1037/0021-9010.92.4.1006

Lytle, R., \& Timmerman, E. (2006). Service orientation and performance: An organisational perspective. Journal of Services Marketing, Vol.20, Issue 2, Pp.136-147. DOI:10.1108/08876040610657066

Miles, M. B., Huberman, A. M., \& Saldaña, J., 2014. Qualitative data analysis: A methods sourcebook. 3rd ed. SAGE Publications. Thousand Oaks, CA. Osborne, S \& Hammoud, M.S. (2017). Effective Employee Engagement in the Workplace. International Journal of Applied Management and Technology, Volume 16, Issue 1, Pages 50-67. DOI:10.5590/IJAMT.2017.16.1.04

Ostrom, A.L., Bitner, M.J., Brown, S.W., Burkhard, K.A., Goul, M., Daniels, V.S., Demirkan, H., Rabinovich, E. (2010). Moving Forward and Making a Difference: Research Priorities for the Science of Service. Journal of Service Research. XX(X) 1-33. DOI:10.1177/1094670509357611

Pant, S. (2013). Conceptualising and measuring service culture. Unpublished project submitted in partial fulfilment of the requirements for the degree of Master of Business, Unitec Institute of Technology, New Zealand.

Roever, L. (2018). PICO: Model for Clinical Questions. Evidence-Based Medicine and Practice. Volume 3, Issue 2, Pp.115-116. DOI: 10.4172/2471-9919.1000115.

Sajari, A., Haron, H., Ismail, I. (2019). Effectiveness Of Quality Of Chief Integrity Officer, Ethical Climate On The Level Of Ethics And Integrity In The Malaysian Federal. Journal Of Governance And Integrity (JGI). Volume 3, Issue 1, Pp.50-68. DOI: 10.15282/jgi.3.1.2019.5422

Schneider, B., White, S.S., \& Paul, M.C. (1998). Linking Service Climate And Customer Perceptions Of Service Quality: Test Of A Causal Model. Journal of Applied Psychology, Vol.83, No.2, Pp.150-163. DOI:10.1037/0021-9010.83.2.150

Suheriadi (2020). Ini Dia Bank Dengan Pelayanan Terbaik Tahun 2020. Retrieved 24 July 2020 via website https://infobanknews.com/topnews/ini-dia-bank-dengan-pelayanan-terbaik-tahun-2020/

Trevino, L. K., \& Weaver, G. R. (2013). Business ethics. Business Ethics Quarterly, Vol.4, Issue 2, Pp. $113-128$. DOI: $10.5840 / 10.2307 / 3857484$

Vargo, S., \& Lusch, R. (2008a). Service-Dominant Logic: Continuing The Evolution. Journal of the Academy of Marketing Science, 36(1), 1-10. DOI: 10.1007/s11747-007-0069-6

Wan, C.D, Chapman, D., Hutcheson, S., Lee, M., Austin, A., \& Ahmad, A. N. (2017). Changing higher education practice in Malaysia: the conundrum of incentives. Studies in Higher Education, Vol.42, Issue:11, Pp.2134-2152. DOI: $10.1080 / 03075079.2015 .1134475$

\section{ACKNOWLEDGEMENT}

Thanks to the Honorable Assoc. Prof. Dr. Yudi Fernando, MBA., Ph.D., M.LogM from the Faculty of Industrial Management, Universiti Malaysia Pahang and the anynomous reviewers who reviewed this article. 


\section{AUTHORS' BIOGRAPHY}

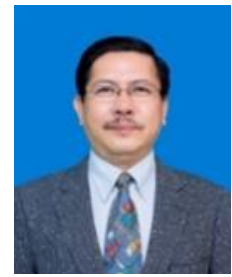

BASUKI RACHMAT has been a lecturer of Accounting Department at State Polytechnic of Malang since 1988. As doctor candidate in Management, Faculty of Economics and Business, Brawijaya University, he is conducting research which offers novelty in the form of a conceptual model "Madani's Service Culture".

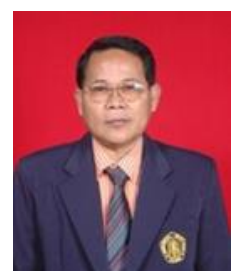

SURACHMAN is a Professor in Management, Faculty of Economics and Business, Brawijaya University Malang. He is an expert in the areas of Operations \& Flexibility Management, as well as Entrepreneurship \& Business Ethics. Professor Surachman is one of supervisors of research on "Madani's Service Culture".

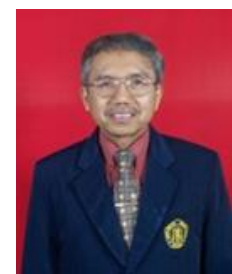

ARMANU is a Professor in Management, Faculty of Economics and Business, Brawijaya University. His major in Human Resource Management and his research interest in organizational culture and entrepreneurship. Professor Armanu is one supervisor of research on "Madani's Service Culture".

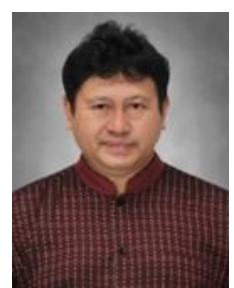

FATCHUR ROHMAN is a senior lecturer and candidate professor in Management, Faculty of Economics and Business, Brawijaya University Malang. He is an expert in the areas of Operational Research, Business Research Methodology \& Service Marketing. He is one of supervisors of research on "Madani's Service Culture". 